УДК 339.138:005.21:005.591.61

DOI: $10.15673 /$ fie.v10i2.959

Лагодієнко В.В.

доктор економічних наук, професор

E-mail: volodymyr@wiktoriya.com
Голодонюк О.М.

старший викладач

E-mail: kaf.mpit@gmail.com

Мільчева В.В.

здобувач

кафедра маркетингу, підприємництва і торгівлі

Одеська національна академія харчових технологій

вул. Канатна, 112, м. Одеса, Україна, 65039

E-mail: milchewa.v@gmail.com

\title{
МАРКЕТИНГОВА СТРАТЕГІЯ ВИВЕДЕННЯ НА РИНОК ІННОВАЦІЙНОГО ПРОДУКТУ
}

В даній статті розглянуто теоретичні аспекти формування маркетингової стратегії підприємства. Проаналізовано мікро- та макросередовище ПрАТ «Одесавинпром», проаналізовано конкурентне середовище підприємства, проведено портфельний аналіз стратегічних зон господарювання (СЗГ) та обрано товарну стратегію за допомогою матриці І. Ансофффа «товар-ринок». На основі проведеного аналізу було прийнято рішення про диверсифікацію портфеля шляхом впровадження у виробництво нового сиропу «Здоровіт», отриманого шляхом переробки вторинної сировини виноробства на продукти з високим вмістом біологічно активних речовин і досліджені вимоги споживачів до інноваційного продукту за допомогою маркетингового дослідження.Розроблено комплекс функціональних маркетингових стратегій та проект заходів щодо просування інноваційного продукту на ПрАТ «Одесавинпром». Обгрунтовано маркетингову і економічну доцільність впровадження запропонованого проекту.

Ключові слова: маркетингова стратегія, диверсифікація, інноваційний продукт, аналіз, медіаплан.

This work is licensed under a Creative Commons Attribution 4.0 International License http://creativecommons.org/licenses/by/4.0/

Постановка проблеми та їі зв'язок з важливими науковими та практичними завданнями. Виноградарство - це апріорі дуже важка та витратна діяльність, яка вимагає багато часу та зусиль. Тому, без державних програм підтримки досягти успіху виноградарству та виноробству, як повноцінній галузі, неможливо.

Виноробні підприємства усі зусилля покладають на те, щоб вижити, намагаються всіма можливими засобами зменшити собівартість продукції для зниження ціни та отримання додаткових конкурентних переваг. Але більшість виробників відмовляються від можливості переробки вторинної сировини виноробства (виноградних кісточок та вичавок), що дозволило б забезпечити комплексну переробку сировини, зекономити кошти та розширити асортимент продукції, яка пропонується, створивши нову стратегічну зону господарювання.

Аналіз останніх публікацій по проблемі. Існує велика кількість стратегій, які допомогли багатьом окремим підприємствам стабілізувати свою економічну діяльність та вийти 3 кризи або запобігти їй. Їх розробниками є всесвітньо відомі автори, які досягли успіху, вивчаючи стратегічне планування та управління, такі як I. Ансофф (матриця «товарринок»), М. Портер (модель п’яти конкурентних сил), Ф. Котлер, М. Мескон та ін.
Формулювання цілей дослідження. Метою та завданням дослідження $є$ розробка маркетингової стратегї̈ проекту переробки вторинної сировини виноробства на продукти 3 високим вмістом біологічно активних сполук.

Виклад основних результатів та їх обгрунтування. На даний момент, стан ринку вина можна констатувати як важкий: виробництво скорочується, сировинна проблема залишається та поступово набуває ще більшої гостроти та актуальності, а відсутність належної державної фінансової підтримки виноградарства ставить під загрозу бізнес, який розвивався роками [1].

В цих умовах, щоб утриматись на ринку і забезпечити стабільний фінансовий стан кожному виноробному підприємству вкрай необхідно розробити дієву маркетингову стратегію для визначення перспективних напрямів розвитку свого виробництва.

Дана наукова робота виконувалась на базі підприємства ПрАТ «Одесавинпром», яке спеціалізується на виробництві шампанського, тихих вин і коньяку.

Це підприємство має багатий досвід виживання в умовах перебудови країни і економічної кризи. Втримати ринкові позиції стало можливим завдяки тому, що ПрАТ «Одесавинпром» завжди величезну увагу приділяє якості продукції, яку виготовляє. 
Саме цей аспект знайшов відображення у місії підприємства: «Виробництво високоякісної продукції для задоволення потреб споживачів». Девізом ПрАТ «Одесавинпром» давно став вислів «Якість понад yce!» [2].
Для розробки і обрання ефективної маркетингової стратегії підприємства нами були проведені наступні види аналізу: SWOT-аналіз, PEST-аналіз, аналіз п'яти сил конкуренції М. Портера, аналіз стратегічних зон господарювання за допомогою матриці БКГ, аналіз матриці I. Ансоффа «товар-ринок», анкетування.

Таблиця 1

SWOT-аналіз ПрАТ «Одесавинпром»*

\begin{tabular}{|c|c|c|}
\hline & Сильні сторони (S) & Слабкі сторони (W) \\
\hline & $\begin{array}{l}\text { Легендарна історія підприємства. } \\
\text { Наявність резерву виробничих потуж- } \\
\text { ностей. } \\
\text { Сучасне обладнання, передові техно- } \\
\text { логії. } \\
\text { Власна сировинна база. } \\
\text { Наявність сучасної лабораторії. } \\
\text { Випуск ексклюзивної виноробної } \\
\text { продукції під власними торгівельними } \\
\text { марками. } \\
\text { Ефективна робота відділу маркетингу. } \\
\text { Традиційна висока якість продукції. } \\
\text { Популярність продукції у всіх регіо- } \\
\text { нах України і за їі межами. } \\
\text { Компетентне керівництво } \\
\text { Висока міра впізнаваності торгової } \\
\text { марки. } \\
\text { Добре розвинена система збуту. } \\
\end{array}$ & $\begin{array}{l}\text { Високі витрати на виробни- } \\
\text { цтво продукції. } \\
\text { Тривалість процесу ухва- } \\
\text { лення управлінських рішень } \\
\text { унаслідок великого числа } \\
\text { узгоджень. } \\
\text { Обмеженість рекламного } \\
\text { бюджету. } \\
\text { Недостатньо високий рівень } \\
\text { корпоративної культури. } \\
\text { Великі витрати на утиліза- } \\
\text { цію відходів (вторинної си- } \\
\text { ровини виробництва вина) }\end{array}$ \\
\hline $\begin{array}{l}\text { Пропаганда здорового способу життя та } \\
\text { культури споживання алкогольних напоїв. } \\
\text { Резерв підвищення середньодушового } \\
\text { вжитку до рівня європейських країн. } \\
\text { Зростання купівельної спроможності на- } \\
\text { селення. } \\
\text { Сприятливі кліматичні умови для виро- } \\
\text { щування винограду. } \\
\text { Участь у міжнародних семінарах і вистав- } \\
\text { ках-ярмарках. } \\
\text { Наявність неосвоєних ринків збуту (віт- } \\
\text { чизняних і зарубіжних). } \\
\text { Поява нових технологій. } \\
\text { Інвестиційна привабливість галузі. } \\
\text { Існування ненасичених цінових сегментів } \\
\text { та неохоплених сегментів споживання. } \\
\text { Учбова база для навчання персоналу } \\
\text { Переробка вторинної сировини на проду- } \\
\text { кти з високим вмістом біологічних сполук } \\
\end{array}$ & $\begin{array}{l}\text { Розширення асортименту продукції за } \\
\text { рахунок освоєння натуральних сорто- } \\
\text { вих вин. } \\
\text { Підвищення якості продукції за раху- } \\
\text { нок нових технологій. } \\
\text { Позиціонування підприємства як ле- } \\
\text { гендарного підприємства галузі. } \\
\text { Проникнення на нові ринки збуту. }\end{array}$ & $\begin{array}{l}\text { Зниження собівартості про- } \\
\text { дукції і ціни на неї за раху- } \\
\text { нок появи нових ресурсо- та } \\
\text { енергозберігаючих техноло- } \\
\text { гій } \\
\text { Проведення тренінгів по } \\
\text { підвищенню рівня професіо- } \\
\text { налізму і корпоративної ку- } \\
\text { льтури. } \\
\text { Комплексна переробка сиро- } \\
\text { вини з метою виробництва } \\
\text { нових інноваційних продук- } \\
\text { тів (диверсифікація портфе- } \\
\text { лю). }\end{array}$ \\
\hline Загрози (T) & (ST)-стратегічні рішення & (WT)-стратегічні рішення \\
\hline $\begin{array}{l}\text { Нестабільна економічна і політична ситу- } \\
\text { ація в країні. } \\
\text { Низька купівельна спроможність насе- } \\
\text { лення. } \\
\text { Жорстка система оподаткування. } \\
\text { Поява на ринку нових конкурентів. } \\
\text { Високі вхідні бар'єри у зв'язку із струк- } \\
\text { турованістю ринку. } \\
\text { Обмеження комунікаційної політики, } \\
\text { встановленні законом «Про рекламу». } \\
\text { Відсутність державної підтримки. } \\
\text { Обмеженість в кредитуванні. } \\
\text { Низька врожайність винограду. }\end{array}$ & $\begin{array}{l}\text { Залучення інвестицій для реалізації } \\
\text { нових проектів шляхом розробки біз- } \\
\text { нес-плану. } \\
\text { Створення вин для стабільних цінових } \\
\text { сегментів (середній плюс і вищий). }\end{array}$ & $\begin{array}{l}\text { Запуск проекту без інвести- } \\
\text { ційної підтримки. } \\
\text { Оптимізація витрат на кому- } \\
\text { нікації. } \\
\text { Просування товару засобами } \\
\text { мерчандайзингу. }\end{array}$ \\
\hline
\end{tabular}

* Складено авторами на підставі аналізу джерел [1] 
Проведений SWOT-аналіз (табл.1) дозволив не тільки виявити сильні та слабкі сторони ПрАТ «Одесавинпром», його можливості та загрози, але й сформулювати стратегічні рішення в кожному полі і визначити, що найбільш перспективним $є$ комплексна переробка вторинної сировини з метою виробництва нових інноваційних продуктів (диверсифікація портфелю).

Проведений PEST-аналіз та кількісна оцінка впливу факторів макросередовища (табл. 2) допомогли визначити, що економічні фактори займають перше місце серед факторів розвитку підприємства та суспільства в цілому. Вони визначаються тим, що слабка економіка держави різко зменшує можливості організації на одержання кредиту й інших ресурсів, необхідних для нормального функціонування [3].

На другому місці технологічні фактори. Так як, швидкість зміни технологій постійно зростає.

Таблиця 2

Ступінь впливу факторів макросередовища на підприємство*

\begin{tabular}{|c|c|c|c|c|c|c|c|c|}
\hline \multirow{2}{*}{ Опис фактору } & \multirow{2}{*}{$\begin{array}{c}\text { Вплив } \\
\text { фактору }\end{array}$} & \multicolumn{5}{|c|}{ Експертна оцінка } & \multirow{2}{*}{$\begin{array}{c}\text { Середня } \\
\text { оцінка }\end{array}$} & \multirow{2}{*}{$\begin{array}{c}\text { Оцінка } 3 \\
\text { поправкою } \\
\text { на вагу }\end{array}$} \\
\hline & & 1 & 2 & 3 & 4 & 5 & & \\
\hline \multicolumn{9}{|c|}{ ПОЛІТИЧНІ ФАКТОРИ } \\
\hline $\begin{array}{l}\text { Недостатні політичні воля і адміністратив- } \\
\text { ний ресурс держави по усуненню тіньових } \\
\text { схем бізнесу }\end{array}$ & 1 & 5 & 4 & 3 & 5 & 4 & 4,2 & 0,16 \\
\hline $\begin{array}{l}\text { Неринкові неекономічні форми регулювання } \\
\text { цін на продукцію підприємства з боку влад- } \\
\text { них структур різних рівнів }\end{array}$ & 2 & 1 & 3 & 2 & 3 & 3 & 2,4 & 0,18 \\
\hline \multicolumn{9}{|c|}{ ЕКОНОМІЧНІ ФАКТОРИ } \\
\hline Економічна криза & 3 & 5 & 4 & 4 & 3 & 4 & 4,0 & 0,44 \\
\hline Курси основних валют & 2 & 1 & 2 & 3 & 1 & 1 & 1,6 & 0,12 \\
\hline Рівень інфляції та процентні ставки & 3 & 5 & 5 & 5 & 5 & 5 & 5,0 & 0,56 \\
\hline \multicolumn{9}{|c|}{ СОЦІАЛЬНО-КУЛЬТУРНІ ФАКТОРИ } \\
\hline $\begin{array}{l}\text { Співвідношення дорослого і дитячого насе- } \\
\text { лення }\end{array}$ & 1 & 5 & 5 & 5 & 5 & 5 & 5,0 & 0,19 \\
\hline Традиції споживання & 3 & 3 & 2 & 3 & 2 & 2 & 2,4 & 0,27 \\
\hline Здорове харчування & 2 & 3 & 4 & 5 & 5 & 4 & 4,2 & 0,31 \\
\hline \multicolumn{9}{|c|}{ ТЕХНОЛОГІЧНІ ФАКТОРИ } \\
\hline Морально і фізично застаріле устаткування & 3 & 4 & 5 & 5 & 4 & 5 & 4,6 & 0,51 \\
\hline Використання енергоємних технологій & 3 & 3 & 4 & 5 & 2 & 4 & 3,6 & 0,40 \\
\hline ВСБОГО & 23 & & & & & & 37,0 & \\
\hline
\end{tabular}

* Складено авторами на підставі аналізу джерел [1]

Конкурентний аналіз галузі по М. Портеру (табл. 3) допоміг визначити інтенсивність та вираженість конкурентних сил в галузі та встановити, що рівень конкуренції в досліджуваній галузі достатньо високий і складає 86 \% від максимуму (12,95 балів 3 15 можливих).

Таблиця 3

Середня оцінка стану конкурентного середовища в галузі*

\begin{tabular}{|l|c|}
\hline \multicolumn{1}{|c|}{ Фактор } & Оцінка чинника \\
\hline Загроза появи нових гравців & 1,9 \\
\hline Ринкова влада покупців & 0,95 \\
\hline Ринкова влада постачальників & 2,6 \\
\hline Загроза появи товарів-замінників & 2,6 \\
\hline Рівень внутрішньогалузевої конкуренції & 4,9 \\
\hline Загальна оцінка & 12,95 \\
\hline
\end{tabular}

* Авторська розробка 
Проаналізувавши склад ділового портфеля ПрАТ «Одесавинпром» (рис. 1) можна сказати, що він $є$ збалансованим: на підприємстві $є$ і проблемні товари (коньяк, який потрапив у зону «собаки») i продукти (тихі вина і шампанське), які приносять прибуток, але потребують значних коштів для підтримання росту. А це в теперішній час забезпечити вкрай важко.

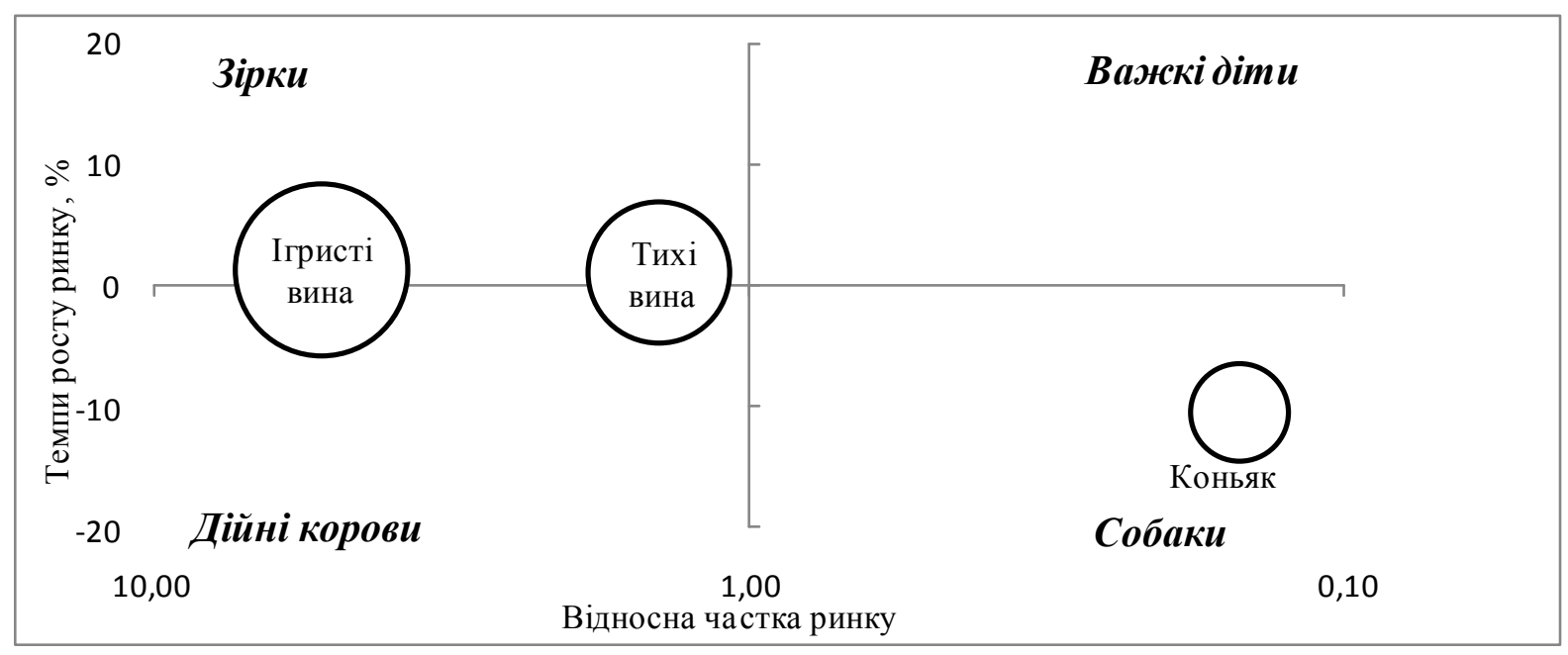

Рис. 1. Матриця БКГ для ПрАТ «Одесавинпром» за 2015 рік*

* складено авторами на підставі аналізу джерел [6]

Аналіз матриці І. Ансоффа «товар-ринок» (табл. 4) дозволив визначитися з товарною стратегією ПрАТ «Одесавинпром» і підтвердив, що перспективними напрямами розвитку підприємства $\epsilon$ розширення асортименту шляхом впровадження нових видів виноро- бної продукції, а також створення інноваційних продуктів за рахунок комплексної переробки вторинної сировини, тобто обрання маркетингової стратегії диверсифікації.

Результати аналізу стратегій по І. Ансоффу*

\begin{tabular}{|c|c|c|c|}
\hline Варіант стратегії & Можливість & Опис & $\begin{array}{l}\text { Джерела росту } \\
\text { компанії }\end{array}$ \\
\hline $\begin{array}{l}\text { Стратегія } \\
\text { проникнення }\end{array}$ & Не можлива & $\begin{array}{l}\text { У компанії є шанси для реалізації цієї стратегії, } \\
\text { але вона не має перспектив. }\end{array}$ & \multirow{4}{*}{$\begin{array}{l}\text { 1. Розробка за- } \\
\text { ходів для стиму- } \\
\text { лювання частоти } \\
\text { покупок вина. } \\
\text { 2. Вихід на новий } \\
\text { ринок з новим } \\
\text { інноваційним } \\
\text { продуктом }\end{array}$} \\
\hline $\begin{array}{l}\text { Стратегія розвит- } \\
\text { ку ринку }\end{array}$ & Не можлива & $\begin{array}{l}\text { Компанія не має можливості реалізувати цю } \\
\text { стратегію. }\end{array}$ & \\
\hline $\begin{array}{l}\text { Стратегія розвит- } \\
\text { ку товару }\end{array}$ & Не можлива & $\begin{array}{l}\text { Компанія має можливості розширення асорти- } \\
\text { менту підприємства за рахунок виведення на } \\
\text { ринок нових видів вина, але в цьому не має } \\
\text { необхідності. }\end{array}$ & \\
\hline $\begin{array}{l}\text { Стратегія дивер- } \\
\text { сифікації }\end{array}$ & Можлива & $\begin{array}{l}\text { Підприємство має усі шанси вийти на новий } \\
\text { ринок із новим товаром. }\end{array}$ & \\
\hline
\end{tabular}

* Авторська розробка

Ідея створення інноваційного продукту належить доктору технічних наук, професору кафедри технології вина і енології ОНАХТ Ларисі Анатоліївні Осиповій. Завдяки іiі науковій розробці був запропонований унікальний продукт, який виробляється виключно з натуральної сировини - гребенів винограду. У його складі немає консервантів, барвників і ГМО. Це продукт нового покоління, який діє на клітинному рівні і значно підвищує якість життя людей в умовах несприятливої економічної та екологічної обстановки [9].

Завдяки своїм корисним властивостям новий інноваційний продукт отримав назву «Здоровіт», що в перекладі означає «здорове життя». Він представляє собою сироп 3 високим вмістом біологічно активних сполук.

Це продукт нового покоління, який значно підвищує якість життя людей в умовах несприятливої економічної і екологічної обстановки. Завдяки своїм корисним властивостям даний товар отримав назву «Здоровіт», що в перекладі означає «здорове життя».

Цей унікальний продукт виробляється виключно з натуральної сировини - гребенів винограду. У його складі немає консервантів, барвників і ГМО. 
Представлений сироп має широкий спектр діï, працює на клітинному рівні і використовується для профілактики і лікування понад 60-ти захворювань.

Сироп «Здоровіт»:

- виводить 3 організму токсини, шлаки, зв'язує вільні радикали;

- підвищує імунітет (що особливо важливо під час епідемії простудних захворювань);

- покращує пам'ять i роботу серцевосудинної системи;

- володіє капіляро-зміцнюючим ефектом та захистом печінки;

- підвищує гемоглобін і покращує формулу крові;
- зміцнює ендокринну, бронхолегеневу, кістково-м'язову, лімфатичну і сечостатеву системи.

«Здоровіт» - сироп, призначений для створення оптимальних дієтологічних умов регулювання антиоксидантного балансу організму. Він сприяє уповільненню процесів передчасного старіння та відновленню структури хромосом, пошкоджених іонізуючим випромінюванням.

В ході маркетингового дослідження було проведено анкетне опитування споживачів 3 метою вивчення їх смаків, запитів та переваг відносно продукту, що пропонується.

Отримані наступні результати: більше половини опитуваних підтримують здоровий спосіб життя (рис. 2-3).

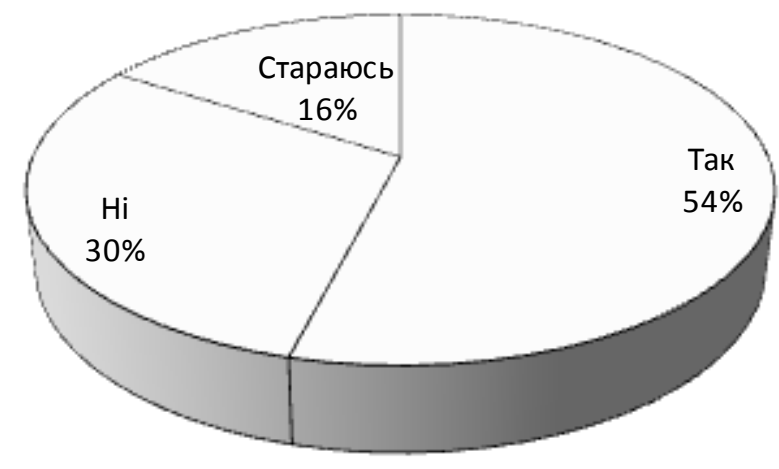

Рис. 2. Структура споживачів, які ведуть здоровий спосіб життя* *складено авторами на підставі анкетного опитування

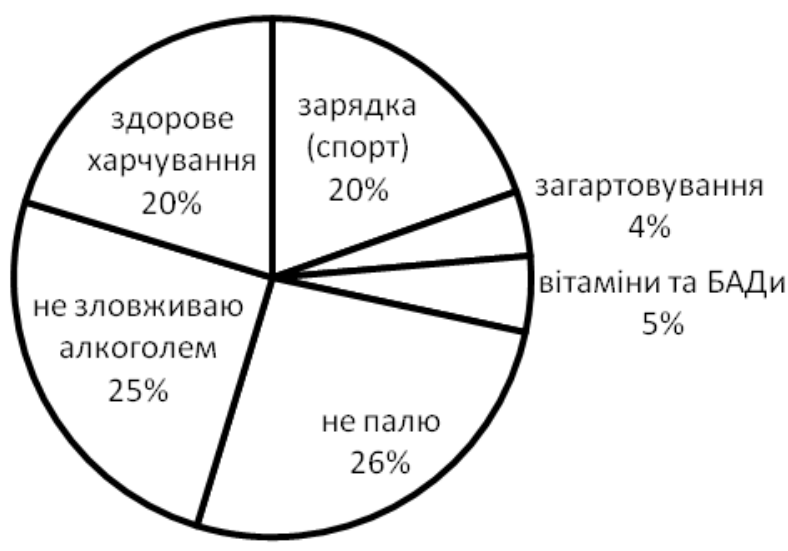

Рис. 3. Перевага за способами підтримки здорового способу життя* *складено авторами на підставі анкетного опитування

Дізнавшись про корисні властивості нового інноваційного продукту $69 \%$ опитуваних згодилися його приймати і лише 39 \% - відмовились (рис. 4-5).

Один курс вживання сиропу триває 2-3 тихі. $45 \%$ опитуваних вважають необхідним проводити два такі курси на рік, 36 \% споживачів згодні прийма- ти сироп три курси на рік, 19 \% опитаних достатньо одного курсу на рік.

Отримані результати були враховані при визначені ємності ринку збуту інноваційного продукту у м. Одесі та Одеській області. 


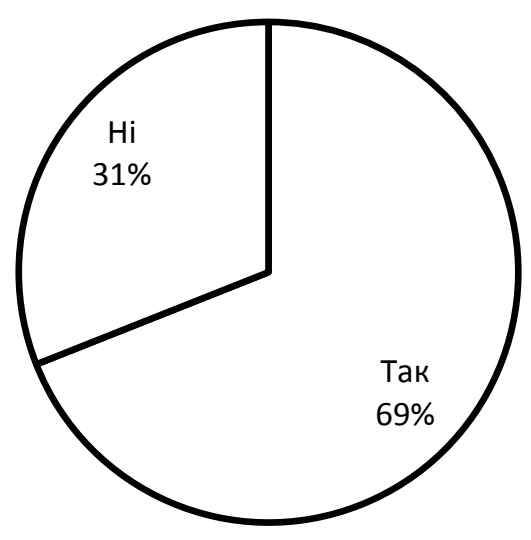

Рис. 4. Згода споживачів купувати інноваційний продукт* *складено авторами на підставі анкетного опитування

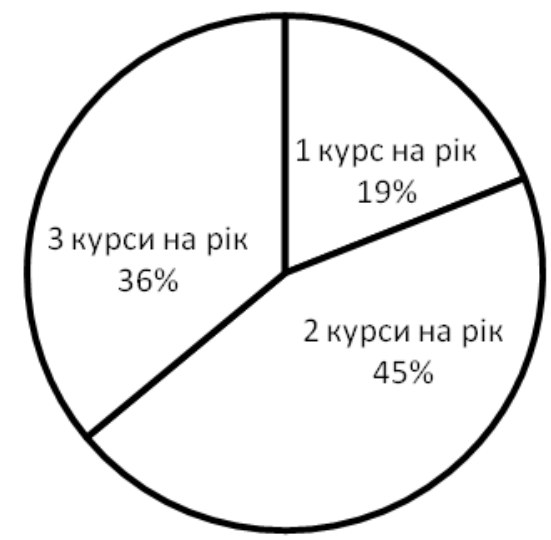

Рис. 5. Перевага споживачів за частотою вживання сиропу* *складено авторами на підставі анкетного опитування

Смність ринку розрахуємо за формулою 1:

$$
\mathrm{E}=\mathrm{U}_{\mathrm{H}} \cdot \mathrm{K}_{1} \cdot \mathrm{K}_{2} \cdot \text { ЧВП } \cdot \mathrm{i}
$$

де Е - ємність ринку

$\mathrm{Ч}_{\mathrm{H}}-$ чисельність населення м. Одеси та Одеської області, чол.;
$\mathrm{K}_{1}$ - частка опитуваних, які погодилися вживати продукт;

$\mathrm{K}_{2}$ - частка населення потрібного віку;

ЧВП - частота вживання продукту за рік;

i - інтенсивність споживання продукту за рік.

Отримані результати показані в таблиці 5.

Смність ринку збуту інноваційного продукту для дитячого та дорослого населення*

\begin{tabular}{|c|c|}
\hline Курс вживання 2 тижні & Курс вживання 3 тижні \\
\hline $\mathrm{E}_{\text {дит }}=2945,67$ дал & $\mathrm{E}_{\text {дит }}=4418,51$ дал \\
$\mathrm{E}_{\text {дор }}=51687$ дал & $\mathrm{E}_{\text {дор }}=77530,5$ дал \\
\hline Разом: 54632,67 дал & Разом: 81949 дал \\
\hline
\end{tabular}

* Авторська розробка

Проведені розрахунки показали, що ємність ринку по сиропу «Здоровіт» складає 54,6 тис. дал (при курсі вживання 2 тижні) та 81,9 тис. дал (при курсі вживання 3 тижні). Для того, щоб переконатися у бажанні споживачів купувати цей продукт та запобігти втратам у разі невдачі на перший рік було заплановано виробництво 36,6 тис. дал. Така різниця в обсягах свідчить про те, що підприємство має всі ша- нси виробляти значно більше сиропу, адже попит на цю продукцію суттєво перевищує пропозицію.

Якщо дані розрахунків підтвердяться, продукція буде вдало реалізуватися на ринку м. Одеси та Одеської області, а ПрАТ «Одесавинпром» отримає бажаний прибуток, обсяги виробництва будуть збільшуватися, а ринок збуту розширюватися спочатку у межах країни, а в перспективі - і за кордоном. 
За результатами опитування споживачів, було вирішено продавати «Здоровіт» в пляшці обсягом 250 мл.

Під час роботи над проектом було розроблено пляшку для сиропу. Вона має квадратну форму, яка плавно переходить у вузьке та акуратне горлечко. Для закупорки пляшки було обрано сучасну та зручну у використанні кришку у вигляді дозатора, який дозволяє 3 легкістю та без додаткових зусиль дозувати продукцію.

На пляшці розташовані кольєретка та етикетка.

На кольєретці зображено логотип продукції. Символ логотипу включає дві головні літери назви товару (3 - здоров'я та В - віта (життя)). Надпис навколо цього символу розшифровує його значення: «Здоровіт - здорове життя!».

На етикетці зображений виноград, який символізує походження цього товару. Також на ній зазначені назва продукту, об'єм пляшки та є зображення кришки-дозатора у відкритому положенні з приміткою «EasyDosage» (легке дозування).

Враховуючи унікальні властивості товару, що пропонується та його соціальну значимість для оздоровлення людини, було вирішено при встановлені ціни керуватися стратегією «проникнення на ринок», яка передбачає вихід з товаром на ринок за відносно низькими цінами, які дозволять зробити його більш доступним для широкого кола споживачів.

Розрібна ціна пляшки = Оптова ціна (з ндс) . $1,25=47,85$ грн.

де 1,25 - 25 \% торгова націнка

ПрАТ «Одесавинпром» формує в регіонах України власну збутову мережу для реалізації своєї продукції.
Але, зважаючи на специфіку виробництва та вжитку інноваційної продукції «Здоровіт», ПрАТ «Одесавинпром» доведеться розширити власну збутову мережу та обрати найбільш ефективні канали збуту для його просування на ринок.

Враховуюче вищесказане, рекомендуємо наступні канали збуту: аптеки, поліклініки, лікарні, санаторії, пологові будинки, будинки відпочинку, школи, дитячі садки, різні посередницькі організації дистриб'юторів та дилерів.

Для стимулювання збуту сиропу «Здоровіт» передбачається провести рекламну кампанію. Вона буде спрямована на цільову аудиторію покупців продукту, що пропонується, якою є люди віком від 21 року. Хоча сироп «Здоровіт» рекомендований до вживання і дітям 3 двох років, але купівлю здійснюють все ж таки дорослі (батьки дитини).

Ціллю даної рекламної кампанії є проінформувати покупців про появу нового продукту (про його корисні властивості та сприятливий вплив на здоров'я людей) та переконати купити даний товар.

Для рекламної кампанії, що планується розроблено три рекламних звернення (для кожного ЗМІ окремо):

- для білборду - ««Здоровіт» - здорове життя у ваших руках!»»»

- для плакату - «Зміцнювати здоров'я і віддаляти старість».

- для листівки - «Здорові діти - щаслива сім’я!»

Також було розроблено рекламний ролик за участю розробників проекту.

Таблиця 6

Витрати на рекламну кампанію ПрАТ «Одесавинпром»*

\begin{tabular}{|c|c|c|c|}
\hline Рекламні носії & Кількість виходів & Ціна, грн. & Вартість, грн. \\
\hline & \multicolumn{3}{|c|}{ Телебачення } \\
\hline Україна & 140 & 820 & 114800 \\
\hline СТБ & 140 & 700 & 98000 \\
\hline HTH & 140 & 340 & 47600 \\
\hline Домашній & 140 & 250 & 35000 \\
\hline \multirow[t]{2}{*}{ Разом } & & & 295400 \\
\hline & \multicolumn{3}{|c|}{ Радіо } \\
\hline Просто Радіо & 280 & 580 & 162400 \\
\hline Народне Радіо & 280 & 460 & 128800 \\
\hline Наше Радіо & 280 & 380 & 106400 \\
\hline \multirow[t]{2}{*}{ Разом } & & & 397600 \\
\hline & \multicolumn{3}{|c|}{ Журнали } \\
\hline Теленеделя & 1 & 25076,3 & 25076,3 \\
\hline \multirow[t]{2}{*}{ Разом } & & & 25076,3 \\
\hline & \multicolumn{3}{|c|}{ Печатні видання } \\
\hline Листівки & 1000 & 0,50 & 500 \\
\hline \multirow[t]{2}{*}{ Плакати } & 3200 & 5,00 & 16000 \\
\hline & \multicolumn{3}{|c|}{ Зовнішня реклама } \\
\hline Білборди & 20 & 3000 & 60000 \\
\hline
\end{tabular}


Продовженя табл.6

\begin{tabular}{|l|c|c|c|}
\hline \multicolumn{1}{|c|}{ Рекламні носії } & Кількість виходів & Ціна, грн. & Вартість, грн. \\
\hline & - & 13500 & 13500 \\
\hline Просування сайту & - & 2600 & 2600 \\
\hline Банерна реклама & & & $\mathbf{1 6 1 0 0}$ \\
\hline Разом & & & $\mathbf{8 1 0 6 7 6 , 3}$ \\
\hline РАЗОМ & & & Інтернет \\
\hline
\end{tabular}

* Авторська розробка

Згідно з проведеними розрахунками, витрати на рекламну кампанію складуть 810,7 тис. грн. (табл. $6)$.

IIÏ ефективність була оцінена за допомогою показника ROMI - коефіцієнта, який вказує на рівень дохідності або збитковості рекламної кампанії, враховуючи суму бюджету на маркетингові заходи (формула 2).

$$
R O M I=\frac{\text { Прибуток-Витрати на рекламу }}{\text { Витрати на рекламу }}=\frac{17975,58-810,7}{810,7}=21,17
$$

Його значення перевищує 0, що свідчить про фінансову вигоду від запропонованого маркетингового бюджету на рекламну кампанію, а також є доцільним і рентабельним для підприємства.

Розрахувавши вплив запропонованого проекту переробки вторинної сировини на продукти 3 високим вмістом біологічно активних сполук на основні показники діяльності ПрАТ «Одесавинпром» встановили, що він позитивно вплине на фінансову діяльність ПрАТ «Одесавинпром». Чистий дохід (виручка) від реалізації продукції збільшиться на 51446,3 тис. грн. $(15,89 \%)$.

Витрати на 1 грн. чистої виручки від реалізації зменшаться на 4,72 коп. (4,77 \%). Рентабельність продукції складе 5,1 \%, що на 3,96 пункти більше ніж до проекту.

Висновки та перспективи подальших досліджень. Отже, провівши маркетинговий аналіз діяльності ПрАТ «Одесавинпром» та маркетингове дослідження ринку і споживачів, дійшли висновку, що для покращення фінансового становища підприємства слід диверсифікувати його товарний портфель шляхом переробки вторинної сировини виноробства на продукти 3 високим вмістом біологічно активних сполук.
У ході роботи по проекту була розроблена біологічно активна добавка (сироп) або бальзам. Науковою новизною даного дослідження $\epsilon$ розробка стратегії виведення на ринок інноваційного продукту 3 високим вмістом біологічно активних сполук на основі оцінки стану ПрАТ «Одесавинпром» на ринку вина в Україні у період економічної кризи.

Практична значущість одержаних результатів полягає в розробці комплексу функціональних маркетингових стратегій для поліпшення фінансового стану підприємства на ринку України.

Подальше вивчення питань формування маркетингової стратегії виведення на ринок інноваційного продукту на підприємстві дозволить детальніше розглянути проблеми стратегічного планування виноробних підприємств та розробити механізм впровадження комплексу стратегій.

Таким чином, активна науково-дослідна й інноваційна діяльність вчених та виробників дозволили одержати унікальний продукт, який на даний момент не має аналогів в Україні і зможе зайняти свою нішу на ринку.

\section{Література}

1. Інвестиційний портал «Огляд ринку вина в Україні» [Електронний ресурс]. - Режим доступу: https://inventure.com.ua/analytics/investments/obzor_rynka_vina_ukrainy

2. Французький бульвар «Про компанію» [Електронний ресурс]. - Режим доступу: http://fbulvar.com.ua

3. Калініченко А.Ю. Стратегічний аналіз функціонування підприємства харчової промисловості на основі використання технологій SWOT- та PEST-аналізу / A.Ю. Калініченко // Управління розвитком. - 2013. - № 18. - С. 14-18.

4. Портер М. Конкурентное преимущество. Как достичь високого результата и обеспечить его устойчивость / М. Портер; пер. с англ. Е. Калинина - М.: Альпина Бизнес Букс, 2016. - 1020 с.

5. Микитюк П. BCG-аналіз як інструмент посилення конкурентних переваг підприсмств / П. Микитюк, Т. Фецович // Економіка підприємства у управління виробництвом. - 2014. - № 2. - С. 20-27

6. Річна фінансова звітність емітента [Електронний ресурс]. - Режим доступу: https://smida.gov.ua/db/emitent/year/xml/showform/69800/165/templ 
7. Ансофф И. Стратегическое управление / И. Ансофф. - М.: Экономика, 2005. - 178 с.

8. Інноваційні розробки ОНАХТ «Сироп з гребенів винограду «Здоровіт»» [Електронний ресурс]. - Режим доступу: https://www.onaft.edu.ua/download/innovat/3_14_inovate_Osipova_Lisii_ua.pdf

9. Підручники онлайн «Метод анкетування» [Електронний ресурс]. - Режим доступу: http://textbooks.net.ua/content/view/103/11/

10. Про рекламу: Закон України від 03.07.1996 р. № 270/96-ВР // Відомості Верховної Ради України. 1996. - № 39 від 24.09.96 р. - Ст. 181.: за станом на 06.01.2018 р. [Електронний ресурс]. - Режим доступу: http://zakon2.rada.gov.ua/laws/show/270/96-вр

Стаття надійшла 3.04.2018 Стаття прийнята до друку 17.04.2018 Доступно в мережі Internet 7.07.2018

Лагодиенко В.В.

доктор экономических наук, профессор E-mail: volodymyr@wiktoriya.com
Голодонюк О.М.

старший преподаватель E-mail: kaf.mpit@gmail.com

\section{Мильчева В.В.} соискатель

кафедра маркетинга, предпринимательства и торговли Одесская национальная академия пищевых технологий ул. Канатная, 112, г. Одесса, Украина, 65039

E-mail: milchewa.v@gmail.com

\section{МАРКЕТИНГОВАЯ СТРАТЕГИЯ ВЫВЕДЕНИЯ НА РЫНОК ИННОВАЦИОННОГО ПРОДУКТА}

В данной статье рассмотрены теоретические аспекты формирования маркетинговой стратегии предприятия. Проанализированы микро- и макросреды ЧАО «Одессавинпром», проанализировано конкурентную среду предприятия, проведен портфельный анализ стратегических зон хозяйствования (C3X), избрано товарную стратегию с помощью матрицы И. Ансофффа «товар-рынок» и разработан комплекс фрункциональных маркетинговых стратегий инновационного продукта для ЧАО «Одессавинпром».

К сожалению, из-за отсутствия опыта, многие производители допускают ошибки при стратегическом планировании и несут большие потери, пытаясь реализовать свою продукцию на рынке. Исходя из этого, можно подвести итог, что правильно выбранная маркетинговая стратегия является залогом успеха предприятия. Именно поэтому выбор оптимальной для компании стратегии является важным вопросом в современных условиях развития страны.

Особую значимость этот вопрос приобретает у винодельческих предприятий Украины. Поэтому, чтобы выжить в этих тяжелых условиях, крупные предприятия или ориентируют производство на уже сложившиеся предпочтения потребителей и создают продукцию, которая будет пользоваться спросом, или же, наоборот, диверсифицируют портфель и внедряют в производство инновационные продукты, которых не хватает на полках магазинов.

На основе проведенного анализа было принято решение о диверсификации портфеля путем внедрения в производство нового сиропа «Здоровит», полученного путем переработки вторичного сырья виноделия на продукты с высоким содержанием биологически активных веществ и исследовании требования потребителей к инновационному продукту с помощью маркетингового исследования.

Разработан комплекс функциональных маркетинговых стратегий и проект мероприятий по продвижению нового товара. Обоснованно маркетинговую и экономическую целесообразность внедрения предложенного проекта.

Ключевые-слова: маркетинговая стратегия, диверсификация, инновационный продукт, анализ, медиа-план. 


\author{
Lagodienko V. \\ Doctor of Economics, Professor \\ E-mail: volodymyr@wiktoriya.com
}

\author{
Holodoniuk O. \\ Assistant \\ E-mail: kaf.mpit@gmail.com
}

\author{
Milcheva V. \\ Applicant \\ Department of Marketing, Business and Trade \\ Odessa National Academy of Food Technologies \\ Kanatna str., 112, Odessa, Ukraine, 65039 \\ E-mail:milchewa.v@gmail.com
}

\title{
MARKETING STRATEGY OF THE INNOVATIVE PRODUCT'S CONDUCTING ON THE MARKET
}

In this article, theoretical aspects of forming the marketing strategy of an enterprise have been considered. The micro and macro environments of Odessavinprom have been analyzed, the company's competitive environment has been analyzed, the portfolio analysis of strategic economic zones has been carried out, the commodity strategy has been selected with I. Ansoff's matrix «product-market» and a set of functional marketing strategies for the innovative product for PrJSC «Odessavinprom» has been developed.

Unfortunately, due to a lack of experience, many manufacturers make mistakes in strategic planning and suffer large losses, trying to sell their products on the market. Proceeding from this, it is possible to sum up, that the correctly chosen marketing strategy is the key to the success of the enterprise. That is why the choice of the optimal strategy for the company is an important issue in the current conditions of the country's development.

This issue is especially important for winemaking enterprises in Ukraine. Therefore, in order to survive in these difficult conditions, large enterprises either orient production to the already existing preferences of consumers and create products that will be in demand, or, on the contrary, diversify the portfolio and introduce innovative products that are lacking on store shelves.

On the basis of the analysis, a decision was made to diversify the portfolio by introducing a new «Health» syrup, produced by processing the secondary raw materials of winemaking to the products with a high content of biologically active substances and researching the requirements of consumers for an innovative product through marketing research.

A set of functional marketing strategies and a project for promoting a new product have been developed. The marketing and economic expediency of implementing the proposed project has been justified.

Key words: marketing strategy, diversification, innovative product, analysis, media plan.

\section{References}

1. Investytsiinyi portal «Ohliad rynku vyna v Ukraini». Retrieved from https://inventure.com.ua/analytics/investments/obzor_rynka_vina_ukrainy

2. Frantsuzkyi bulvar «Pro kompaniiu». (2018). Retrieved from http://fbulvar.com.ua

3. Kalinichenko, A. Yu. (2013). Stratehichnyi analiz funktsionuvannia pidpryiemstva kharchovoi promyslovosti na osnovi vykorystannia tekhnolohii SWOT- ta PEST analizu. Upravlinnia Rozvytkom, (18), 14-18.

4. Porter, M. (2016). Konkurentnoe preimuschestvo. Kak dostich visokogo rezultata i obespechit ego ustoychivost (E. Kalinina, Trans.). M.: Alpina Biznes Buks.

5. Mykytiuk, P., \& Fetsovych, T. (2014). BCG-analiz yak instrument posylennia konkurentnykh perevah pidpryiemstv. Ekonomika Pidpryiemstva U Upravlinnia Vyrobnytstvom, (2), 20-27.

6. Richna finansova zvitnist emitenta. Retrieved from

https://smida.gov.ua/db/emitent/year/xml/showform/69800/165/templ

7. Ansoff, I. (2005). Strategicheskoe upravlenie. M.: Ekonomika.

8. Innovatsiini rozrobky ONAKhT «Syrop z hrebeniv vynohradu «Zdorovit»»). Retrieved from https://www.onaft.edu.ua/download/innovat/3_14_inovate_Osipova_Lisii_ua.pdf

9. Pidruchnyky onlain «Metod anketuvannia». Retrieved from http://textbooks.net.ua/content/view/103/11/

10. Pro reklamu: Zakon Ukrainy vid 03.07.1996 r. № 270/96-VR // Vidomosti Verkhovnoi Rady Ukrainy. 1996. - № 39 vid 24.09.96 r. - St. 181.: Za stanom na 06.01.2018 r. (2018). Retrieved from http://zakon2.rada.gov.ua/laws/show/270/96-вр 